\title{
How Do You Know When You're in a Cult?
}

\author{
The Continuing Influence of Peoples \\ Temple and Jonestown in Contemporary \\ Minority Religions and Popular Culture
}

\section{Susannah Crockford}

\begin{abstract}
This article examines representations of Peoples Temple in popular culture through the lens of mimesis, understood as a process of repetition and re-creation of specific elements. This process produces what is understood as a "cult" in popular culture, which is divorced from the complex historical reality of Peoples Temple. Three symbolic strands combine to construct the concept of a "cult": the power of a charismatic leader, isolation from outside influences, and consuming poison, or "drinking the Kool-Aid." In popular culture, these symbols are used in order to apportion blame, to learn lessons, and to act as a warning. Peoples Temple was a collective trauma for American culture as well as an individual trauma for survivors. The process of mimesis, therefore, is a way of both memorializing and reinscribing this trauma on a cultural level. Examples from ethnographic research conducted in Sedona, Arizona, are used to illustrate how symbols of Jonestown generated by cultural mimesis continue to be invoked by participants in contemporary minority religions as a way to signal their concern about whether they belong to a cult.
\end{abstract}

KEYWORDS: minority religions, Peoples Temple, cults, United States of America, mimesis, popular culture

Nova Religio: The Journal of Alternative and Emergent Religions, Volume 22, Issue 2, pages 93-114. ISSN 1092-6690 (print), 1541-8480. (electronic). (c) 2018 by The Regents of the University of California. All rights reserved. Please direct all requests for permission to photocopy or reproduce article content through the University of California Press's Reprints and Permissions web page, http://www.ucpress.edu/journals.php?p=reprints. DOI: https://doi.org/10.1525/nr.2018.22.2.93. 
I f you ask an average American what a cult is, they are likely to refer either implicitly or explicitly to Peoples Temple and the events at Jonestown. Beyond academic circles, the term cult has a salience provided by a small number of culturally defined traits. In this article, I argue that the normativity of the term cult on a cultural level in contemporary America derives from Jonestown. Like any cultural construction, it is a reduction of a complex, variegated original, drawing out specific symbols that then stand metonymically for the whole, messy, historical reality. Peoples Temple became the archetypal cult in popular American culture through three symbolic strands: charisma, isolation, and poison. Each of these symbols represents aspects of the history of Peoples Temple and the deaths at Jonestown on 18 November 1978. Charisma stands for the influence of the leader, Jim Jones (1931-1978), seemingly possessed with the power to control the will of his followers. ${ }^{1}$ Isolation stands for disconnection from society, the group's disappearance into the jungle far away from family and friends looking for the Promised Land. Poison stands for alleged mind control, a corruption of the individual will to survive in favor of the collective; a process given real, tangible form in the story of Jonestown through the problematic phrase "drinking the Kool-Aid." 2 This article explores how each symbolic strand is reproduced and replicated in popular culture, and then juxtaposed with examples from my ethnographic fieldwork in Sedona, Arizona, to illustrate how the legacy of Jonestown persists in discourse among participants of contemporary minority religions.

The limits of popular culture are heuristically set for the purpose of this article as non-academic works such as news reports, animation, documentaries, movies, and artistic works-both literary and mass market fiction. Social theorists including Theodor Adorno, Walter Benjamin, and Jean Baudrillard have long observed that popular culture in America thrives on simulation and replication, decontextualizing elements and repeating and replaying them ad nauseum, for pleasure and profit. ${ }^{3}$ Anthropologist Michael Taussig draws on the observations of these theorists to help develop his theory of mimesis. ${ }^{4}$ For Taussig, mimesis is both a faculty of humans and a history of human contact, and it is his central argument that it is potently found in the history of EuroAmerican colonialism. Mimesis is a process of reproduction. It is a technology of magic that assumes the power of the original through making an image of it. In this article, I will discuss how various documentaries, movies, newspaper articles, blog posts, novels, and animated television series mimetically reproduce the history of Peoples Temple and Jonestown and disseminate it through popular culture. Mimesis is a process through which these artifacts of popular culture do not simply describe a purported cult but construct and essentialize it as inherently dangerous and threatening. 
Popular culture is, in part, a mimetic production through words and pictures that represent cultural and historical events. Jonestown is a singularly harrowing event in American history, and as such it is powerful. Through mimesis, popular culture simulates Jonestown and, in the process, distills the history of Peoples Temple into three symbols, producing the term cult as it is understood on a cultural level. The question "how do you know when you are in a cult?" is answered by holding up representations of Jonestown and examining one's closeness or distance from it. This process ends in a place far from the historical reality of Jonestown, but this is part of what Taussig names as the "unstable" nature of mimesis that veers between essentialism and constructionism. ${ }^{5}$ Popular culture propagates the memory of Peoples Temple in Jonestown, transmits it to new audiences, and generates new interpretations and conceptualizations. It talks in the voice of survivors, but also over them. Mimesis forms part of the cultural process of both the construction of and essentialization of minority religious groups as "cults."

\section{ARE WE IN A GULT?}

In the years immediately following its demise, news reports and the growing anticult movement talked about Peoples Temple as the "paragon of the religious 'cult," with Jim Jones as the embodiment of the dangerous charismatic leader. ${ }^{6}$ Rebecca Moore argues against this characterization because of the numerous facets of the Peoples Temple story that were singular and specific. ${ }^{7}$ However, the cult essentialism model became molded around Peoples Temple, drawing in part from academic terminology. ${ }^{8}$ The term cult in sociological typologies of cult and sect was fairly benign prior to the 1970 s. $^{9}$ Then what happened in Jonestown reinforced many of the popular stereotypes and fears about cults. ${ }^{10}$ It bolstered an anticult movement of purported cult experts and deprogrammers offering to save errant family members from the same fate as those who died in Jonestown. The anticult movement portrayed all alleged cults as inherently dangerous and subject only to internal influences. They figured the charismatic leader as so powerful that he could take captive the minds of his followers and make them do whatever he wanted. Proactive intervention by concerned outsiders was justified through this characterization.

However, scholars rejected the anticult movement's depiction by reevaluating the data on minority religions and finding that most did not fit the essentialist model. The scholarly discourse switched to a more nuanced picture of new religious movements rather than the jeremiads of the anticultists issued against groups they perceived as cults. The decades of the 1970s and 1980s have been called "the cult wars" for the mutual hostility between the two camps. ${ }^{11}$ The brainwashing debate was 
emblematic of the antagonism, which centered on whether brainwashing or mind control is an actual cognitive process that can then be reversed or cured by deprogramming, or whether such terms are historically-situated metaphors used to describe the alienation of a person from the ideological and religious orthodoxy in which they once believed. ${ }^{12}$ Scholars deconstructed the cult essentialist model and more recent scholarship in the field of minority religions takes a more interactionist view that examines how the internal forces of a group respond to external forces, such as ex-members, the media, and the state, in relation to specific events. Few scholars would use the term "cult" as an analytic model today, and most would likely agree with James A. Beckford's assessment that minority religious groups or new religious movements are only marginally different from other voluntary organizations in the problems they experience. ${ }^{13}$ However, outside the small field of scholars specializing in minority religions, Peoples Temple continues to be a stand-in for all new religious movements, the cult archetype by which to evaluate all others. ${ }^{14}$

This tendency is more pronounced in news reports, which talk about cults in general as if minority religious groups are all the same type of phenomenon, than in academic accounts. Cults are all somehow inherently dangerous, any charismatic leader is equivalent to Jim Jones, and followers are deceived or deluded and need to be saved, even against their own will. Eileen Barker contends that journalists since the 1970s have been eager to publish sensationalized stories about minority religions, painting them all as destructive cults, with frequent reference to Peoples Temple, which is used to legitimize negative generalizations about any minority religion. ${ }^{15}$ A 2017 New York Times article exemplifies this trend. Asking "what doomsday cults can teach us about ISIS today," it goes on to make an explicit comparison between the Salafi jihadist group and Peoples Temple. ${ }^{16}$ It compares Jonestown survivor Leslie Wagner-Wilson to a young man who tried to go to Syria to fight for ISIS. Despite the vast historical, cultural, and socioeconomic differences in the two cases, the article claims they are linked by "behavioral threads" and labels both groups "death-hugging cults." Adherents are described as "brainwashed," and the solution is deprogramming, which the article calls deradicalization when applied to jihadists.

News stories illustrate how the essentialist idea of a cult is selfduplicating; this is an example of the process that Taussig refers to as mimesis. For the term cult, the idea is based on a template molded upon Peoples Temple. A 2015 article describing the Word of Life Christian Church in Chadwicks, New York, made an explicit comparison to Jonestown. ${ }^{17}$ The church was in the news after what was called a "counseling session" resulted in the death of 19-year-old Lucas Leonard and the beating of his 17-year-old brother, Christopher. The parents of the young men were prosecuted for manslaughter and other 
church members were charged with second-degree assault. Ex-member Chadwick M. Handville is quoted likening Word of Life's leader to Jim Jones, outlining long days of labor for the benefit of the church and a controlling structure. This is followed by Handville's summary of the situation: "We were sleep deprived and easily manipulated and lied to,' he added 'Everyone knows this is the marking of a cult. This is how you control the masses." Jim Jones and Peoples Temple are invoked to guide the audience into thinking that the Word of Life is also a cult, and why this is dangerous.

The same elements appeared when people tried to describe what they understood as a cult during my two years of fieldwork in Northern Arizona ${ }^{18}$ studying and participating in a range of minority religious activities. My informants applied the word "cult" to those who seemed to have gone too far in some manner. Sedona is a small town in Northern Arizona that has a reputation as a "New Age mecca." 19 People visiting seek out spiritual experiences, and often move there in order to pursue what they call a spiritual path. As a consequence of this, there are many groups in formation, people trying to set themselves up as spiritual teachers, trying to earn a living from their spiritual practice. Many groups do not maintain their existence for long; many individual practitioners leave after failing to support themselves economically. It is a crowded spiritual marketplace. ${ }^{20}$ There is no authorizing institution. Individual seekers have to follow their own judgment, phrased as following their own intuition. Among my informants, when a practice became too onerous for some reason, it was abandoned, without much more explanation than that they were guided elsewhere, what they identified as "spirit" called them to do something else, or they no longer resonated with it. There were a few instances in which a stronger statement was made; they would no longer do that practice or follow that teacher because it was a cult.

One group that I was involved in fell into acrimonious disarray with accusations made that it had become a cult. ${ }^{21}$ The group was a martial arts school run by Joe, a white American man from Tennessee who practiced and taught martial arts. After several months of attending what were called training sessions, the intensity and frequency of these sessions increased gradually. Roger, my fellow student and the one with whom I had the closest relationship, was our teacher's "right hand man," in Joe's own words. As the training sessions required more physical exertion and effort on the part of the students, Joe's behavior became more erratic. Roger told me at the time that Joe seemed "crazy." He talked about a training session in which Joe had seemed to "maul" him "like a tiger." He said he got a scratch mark as if from a tiger's claw along his collarbone. I responded that it seemed as if we did not even think about what we were doing in training, we simply did what Joe said. Some of what we did seemed to be not only intense, but violent. "It is a cult," Roger said, "we are in a cult." 
What linked Roger's experience in the martial arts group to the term cult in his mind was that he felt manipulated by Joe, an individual whom he felt was increasingly influencing and even controlling his and his fellow students' behavior. For him, labeling the group a cult was part of how he began to distance himself from it and eventually abandon it altogether. The term "cult" has a singular power when used in this sort of context. To say, "I am in a cult" means "I have to leave this group." The context of the martial arts group is very different from that of the Word of Life Church in New York State and from that of Peoples Temple. However, the use of the term "cult" connects them in popular discourse. The mimetic reproduction of the term makes certain characteristics dominate and renders the differences unimportant. This is what is so problematic about essentialism. It strips away context and nuance through repeating only certain symbols. In the case of representations of Peoples Temple in popular culture, three symbols predominate, the first of which is the power of the charismatic leader.

\section{CHARISMA}

Jim Jones looms large in representations of Peoples Temple in popular culture. In interviews with surviving Peoples Temple members, the portrayal of Jones is bleak. Stephan Jones, his biological son, describes an abusive, delusional, and controlling father. ${ }^{22}$ Grace Stoen Jones, the mother of John Victor Stoen (1972-1978), saw herself as brainwashed by Jones. She denies that she was a believer, claiming that she stayed from fear of Jones and that he used their child to control her. ${ }^{23}$ Jack Palladino, a private investigator in the Larry Layton defense team, talked about Jones faking stigmata in services, using counterfeit faith healings and miracles to convince people he was God. ${ }^{24}$ Their accounts portray him as a Machiavellian charlatan, who deceived and controlled his followers.

News reports zeroed in on Jim Jones in the immediate aftermath of the deaths at Jonestown. Repeatedly retelling the lurid stories of Jim Jones' behavior reinforced the narrative of the charismatic megalomaniac leader, who duped or brainwashed his followers. The New York Times concluded in the aftermath: "We all need to pay more attention to what we are doing and whom we are listening to." 25 This narrative is repeated in the media on anniversaries. In a 1998 article headlined "Evil in Paradise" in the Edmonton Journal, there is a counterpoise of two images, the evil of Jim Jones with the jungle paradise of Guyana where Jonestown was located. It comprises a false prophet metanarrative: "this sick man marched his people toward a long-rehearsed death rite." 26 The figure of Jones expands to eclipse all others, he is the only individual in the story given a name; any others are just his people. He is the one with agency, they merely follow. 
The 2006 PBS documentary Jonestown: The Life and Death of Peoples Temple similarly foregrounds Jones. However, it speaks through the voices of survivors, relatives, journalists, and scholars. ${ }^{27}$ By using photographs and recordings of the Temple before the establishment of Jonestown, and the NBC footage shot at Jonestown by the camera crew accompanying Congressman Leo Ryan, the documentary shows Temple members as they lived, not just how they died. The substantive inclusion of the Indiana and California periods of the church contributes to a thorough depiction of Peoples Temple. As the documentary does not mention the John Victor Stoen custody case, or any of the other legal cases or investigations by federal agencies, it appears that the New West exposé and Jim Jones' paranoia were the only factors involved in the move to Guyana. The overall impression is of horror caused primarily by Jones, and secondarily by the Temple members' desire to follow him, and not by any social conditions or as a product of circumstances. A review of the documentary posed the question, "How many of us are so desperate for a charismatic leader claiming to have the answers that we will surrender our basic instincts for survival, along with our reason?" Then answers it, "The horror of Jonestown was caused by people's willingness to surrender their reason to a madman who was also a charismatic manipulator. And that can happen anytime and anywhere."28

The 2007 History Channel documentary Jonestown: Paradise Lost also centers on Jones, but has fewer redeeming qualities than the PBS documentary. It is played for sensationalism, with dramatic re-enactments featuring actors. ${ }^{29}$ There are fewer talking heads than the PBS documentary, providing less engagement with survivors and far less in the way of analysis. The accounts of survivors Stephan Jones and Vernon Gosney dominate. It utilizes voice-over narration to link the interviews with the dramatic intervals. Most of the running time is devoted to depicting the deaths. Everything else is simply prelude. In a graphic re-creation, the bodies are seen through the eyes of survivor Hyacinth Thrash. It shows a photograph of Jim Jones' corpse and a shot of the same frame re-enacted by actors. The only motivation for the deaths is advanced by the journalist Tim Reiterman, who was part of the congressional delegation and was shot on the airfield at Port Kaituma. He believes that Jim Jones had Congressman Leo Ryan executed in order to get his followers to kill themselves. It was a mass murder perpetrated by Jones because he did not want the truth of Jonestown to be revealed, exposing him as a fraud and failure. This retelling deprives Jones of charismatic power; the humiliating picture of his corpse, belly exposed, is a graphic image signifying his downfall. The documentary ends with Stephan Jones asking for a lesson to be learned so that the deaths are rendered meaningful.

These documentaries, with varying levels of sophistication, present Jones to explain him, and the explanations result in unequivocal blame. 
The only explanation required is actually about the believers: why did they believe in a fake? But by emphasizing Jones, the people of Peoples Temple disappear. Even when survivors appear telling their stories, the words selected by the producers are all about Jones. The history of Peoples Temple is told as a true-crime genre tale; a criminal, his victims, the scene of the crime. There is a power that Jones has; his charisma. Through mimesis, however, this power is undermined. The man who claimed to be god is but a cult leader. Retelling the story to teach a lesson creates a morality play that assumes Jonestown is a template that could be repeated, and so the depictions operate as a warning.

Lacking the moralizing tone of the documentaries and news reports, in popular fiction the details of Jim Jones' abusive behavior fulfill the crazy cult leader stereotype and prove to be a convenient plot device. ${ }^{30}$ In Jonestown, a novel by Ryan Roy, Jones is a manipulator, inflicting physical punishments in full view of his congregation, having sex with everyone-men and women alike-while calling himself a heterosexual, using deception to reveal others' lies, and tricking people into thinking he has supernatural powers. ${ }^{31}$ Roy's protagonist shoots Jones as he is trying to escape to Cuba with the cash hidden in Jonestown. In the selfpublished novel Jim Jones is Alive, Eugene Mendonsa does not fictionalize the Jonestown story, but instead places Jim Jones as the villain in an alternative future where he is alive, still doing very much the same thing in a different context. ${ }^{32}$ His corruption is intrinsic, not a product of circumstances. Jones is an archetype of villainy in this novel, but again the author grants the power to his fictional survivors to get revenge and kill Jones.

Jones as a sinister being that transcends death and possesses people is also the plot device used in the 2016 horror movie, The Veil. ${ }^{33} \mathrm{Jim}$ Jacobs, the leader of a group called Heaven's Veil, hails from a poor family in Indiana, and has the iconic Jim Jones look, with black hair and aviator sunglasses. The first scene has Jacobs giving a sermon where he throws a Bible away, asking if anyone saw any lightning strike them as a result; this is a replay of a Jones sermon in California (that is also mentioned in the PBS documentary). The film takes elements of the Jonestown story, such as the forced poisoning of children and the voluntary ingesting of the lethal punch by many of the group's members, the leader's habits of drugs and sexual promiscuity, faith healings, and the isolation in the wilderness (in California). But it does not tell the story of the deaths at Jonestown. Instead the elements are used to construct a horror movie in which Jim Jacobs uses drugs to enter the spirit realm and then comes back to possess a documentary crew and the sole survivor of the initial mass suicide. He and his followers are able to continue to wreak havoc after their deaths by going on a killing spree and feeding on the souls of the living. Jones is turned into a villain who is so demonic that he quite literally controls the souls and bodies of 
those he comes into contact with. The horror movie version of Jim Jones is a caricature of his worst side, distorting him into a being of pure evil with the power of possession.

The portrayal of Jim Jones mimetically reproduced in popular culture is the charismatic leader, one who will bring destruction upon those he leads. There are alternative representations that we find in fine art, poetry, drama, and music. ${ }^{34}$ Yet these prove to be the exception rather than the rule. Moreover, these nuanced, ambiguous, and at times disturbing portrayals do not seem to have an effect on wider cultural understandings of the nature of Peoples Temple in particular and new religions in general. Rarely are we invited to look beyond the image of the immoral cult leader to see the person who is being represented.

During my fieldwork in Arizona, my informants talked about the charismatic leader using a local term, the Sedona Alpha Male. The figure who typified this category was James Arthur Ray (b. 1957). On 3 October 2009, three people died while participating in a sweat lodge ritual that was part of Ray's Spiritual Warrior retreat held at Angel Valley, near Sedona. He was later sentenced to two years in prison for negligent homicide. ${ }^{35}$ A Sedona bartender, resident in the town for more than ten years, described how Ray used to come into his bar surrounded by an entourage of young besotted women, tell jokes that only they would laugh at, and generally "strut around like he was great." He was a typical Sedona Alpha Male with his long hair and constant retinue. The phrase invoked a local variant on Jim Jones, often implicitly, but sometimes explicitly. Just as Jones has been portrayed repeatedly through popular culture, those who claimed spiritual leadership were often condemned as frauds.

The martial arts teacher, Joe, suffered this kind of downfall. When Greg, a fellow student, showed Roger and me the bruises on his thighs, we saw that the discoloration and swelling covered most of the lateral and front side of his thighs. Greg admitted that he paid $\$ 30$ to the man who beat him: it had been part of a training session with Joe. Joe claimed a position of authority in martial arts because he had practiced for 24 years and learned from masters in both the United States and China. However, his stories about his teachers contradicted each other and lacked consistency. For a number of reasons, Roger and I became increasingly skeptical about Joe's claims during the period when our training sessions became more brutal, as evidenced by Greg's bruises.

Roger's response to those bruises reflected this process of questioning: What if Joe was making it up? What if we weren't learning an ancient spiritual art from a master practitioner? What if we were being led astray by a maniac? Roger used the word "groupthink" to name a process in which individuals place the priorities of the group over themselves. Soon after seeing Greg's bruises, Roger left the group, rejecting Joe as his 
spiritual teacher. He concluded that Joe had the whiff of imposture, a charlatan making things up to hoodwink others into doing his bidding.

This same current animates the representations of Jim Jones in popular culture. Jones claimed to have special powers; he called himself the messiah. This is symbolized as charisma, a special power that certain humans possess but one that is still a mundane ability. As a meme in popular culture Jones is represented as a phony. He is not the messiah, but at the same time his ability to influence others does grant him power. His charisma reanimates him after death. He is, in cultural terms, an evil spirit. Peoples Temple is portrayed as a cult in which Jones possessed the members and turned them against each other, and eventually themselves.

For Taussig, one of the functions of the mimetic faculty is to protect oneself from evil spirits by portraying them..$^{36}$ Making a copy takes on some of the power of the original, which then can be used as protection from the original, like an inoculation. The representations of Jim Jones as an evil spirit, especially in the documentaries, movies and novels reviewed, re-create him as an archetype in order to protect American culture from future apparitions of his form. His charisma remains the animating force behind what occurred at Jonestown, all other influences fall by the wayside. The context, the setting for the deaths, then emerges in the second symbolic strand flowing through representations of Peoples Temple in popular culture.

\section{ISOLATION}

In the focus on the personality of Jim Jones, it is easy to lose sight of how isolated Jonestown was in Guyana. The character of Jones took on immediate significance in the narratives of Jonestown, but what emerged more gradually in the efforts to comprehend the trauma was the effect of isolation. It is prominent in stories retold by those who survived and by those who have investigated the deaths. Jack Palladino summed it up as, "Jones had essentially marooned everybody as though they were on some tropical island. He had your passport, he had all your money, had total control. You're hundreds of miles from anyplace." ${ }^{37}$ The agricultural project at Jonestown was located in the remote Northwest District of Guyana, an area fifteen miles from the contested border with Venezuela. It was set amidst the jungle. It was hot, densely vegetated, and required a machete to cut through. Residents were beset by insects, snakes, and wild animals. It was not a place that could easily be escaped. Transportation into and out of Jonestown was controlled by Jones. ${ }^{38}$ It meant getting on a tractor dragging a trailer up the single sixmile-long track, followed by a two-hour flight by propeller plane to Georgetown; or, more likely, a 24-hour trip up the Kaituma River and along the coast of South America on one of the two boats that the 
community owned..$^{39}$ Jim Jones also had control of the children. Parents and children lived separately, young children were looked after by adults who were not their biological parents. Some parents relinquished legal custody of their children to the church. Thus there was social isolation alongside the physical isolation.

The effects of isolation are evoked in an interview with Juanita Bogue who grew up in Peoples Temple, and whose family left with Congressman Ryan on 18 November $1978 .{ }^{40}$ She recalls that

they kept rotating everything so you couldn't keep up with anything. We were turning into zombies. We were starving to death. Everybody was just so sickly, losing so much weight, eaten up with all kinds of rashes and everything. You more or less started doing just whatever you were told.

This is a depiction of a group of people who were losing the will to survive. Jim Jones told them there were soldiers out in the jungle, there was no way to escape, and they would be killed if they tried. This level of intense isolation took significant toll in Bogue's account. Afterward, she tells of survivors asking how they let that happen to themselves, how they lost their children, how they lost their sense of self.

Survivor accounts of the agricultural project in Jonestown evoke a paranoid environment, with repeated emergency drills, called White Nights, occurring with increasing regularity. ${ }^{41}$ One of the earliest White Nights was part of a purported six-day siege occurring with the transfer of the John Victor Stoen custody case from California to Guyana. Residents of Jonestown believed they were under attack. According to Stephan Jones, members were wielding knives and guns in fear of enemies who never materialized. ${ }^{42}$ In these and other accounts of White Nights, it is clear that a sense of an outside to reflect back on what was happening is lacking; no other source of information existed other than Jones. It was a different place from Peoples Temple in California, which was engaged with the local community and active in politics. The 2006 PBS documentary includes survivors speaking of the social isolation, how they could not talk to each other honestly for fear of being reported and punished, they could not question Jones, and they could not say they wanted to leave.

In an interview, Teri Buford O'Shea, who fled three weeks before the murder-suicides occurred, emphasizes the complexity of the community and the ordinariness of the members, their good intentions in trying to build an egalitarian community; but she also focuses on the isolation they experienced. ${ }^{43} \mathrm{O}$ 'Shea centers this in her personal definition of a cult. "A cult is when you aren't allowed to see your friends or family ... total isolation, someone takes all your money and brings you to a place where there's no communication, or if there is you aren't allowed to use it." She draws a lesson from Jonestown, "Trust your gut and don't give up your liberties." The exclusion of outside influences 
becomes a symbol for what is so dangerous about certain groups, highlighting the potential for abuse when there is no oversight or interaction with others.

This symbol is repeated as a warning when discussing others who want to live in a community of like-minded people apart from those who differ. In 2013, talk radio host Glenn Beck's planned city of Independence, USA, was augured as the "next Jonestown" by a writer identified only as Mark NC on the website newscorpse.com. ${ }^{44}$ Beck has been a controversial figure in conservative media, once hosting a regular TV show on Fox News. At the time that the News Corpse article was written, Beck was on the opposite side of the political spectrum from Jones' socialism. It is the isolation of Beck's proposed community, however, that concerned Mark NC:

What's troubling is the notion that Beck wants to create a segregated community of followers who believe in his vision and will strike out on their own to build a self-reliant, communal society based on his twisted brand of evangelism and with him as its leader. Sound familiar? It is precisely what Jim Jones, a pastor from California, did when he assembled his flock in Guyana to form what he called Jonestown. That ended in tragedy with more than 900 disciples succumbing to poison-laced Kool-Aid. ${ }^{45}$

Given the history of American idealization of self-sufficient frontier homesteads and rugged individuals, it is telling that Mark NC uses Jonestown to sound a warning about Beck's proposal. It is the sealing off of the community from dissenting voices that creates the danger.

This element of Jonestown's history is replicated and enlarged in "The Joy of Sect" from season nine of The Simpsons. Homer Simpson takes his family to live on an agricultural commune of the invented religious group, the Movementarians. The farmwork is hard and punishing, with escape prevented by an array of obstacles. At the end The Leader of the Movementarians leaves on a spaceship that falls apart, revealing a hoax. Various aspects of the Movementarians were based on different religious groups, but the writer of the episode cited Jonestown as the inspiration for the agrarian community holding people against their will. ${ }^{46}$ In a satirical presentation of new religions that mixes elements from a number of well-known groups, the complex history of Peoples Temple is whittled down to its final chapter, the isolated commune from which escape was prohibitively difficult.

It is this final chapter of Peoples Temple that the novel Children of Paradise, by Fred D'Aguiar, reimagines. ${ }^{47}$ Employing many historical elements, it is a fictional narrative inspired by Jonestown, not a retelling of the story. The narrative makes heavy use of magical realism, which evokes the dreamlike quality of Jonestown: the surreal environment, the sudden switching of emotional registers, the dominating presence of Jim Jones, his phony miracles, such as revivifying a girl who was never really 
dead. D'Aguiar puts the children in the community at the center of the story, but includes the perspective of a caged gorilla named Adam, as well. This framing device mimics the isolation of the commune's members, especially the children. It also calls to mind Taussig's characterization of the "ape aping humanity's aping." 48 In the character of Adam, it appears D'Aguiar is aping Mr. Muggs, a chimpanzee who was moved with Peoples Temple members from California to Guyana. ${ }^{49}$ The gorilla experiences the preacher's dominance as a primal force, not something that one can rationalize; yet he is pivotal in the escape attempt of the main characters at the end. The blurring of fantasy and reality that pervades the book evokes one of the effects of isolation. Yet with the focus on the children and the gorilla, D'Aguiar seems to be examining the power of the mind to remain free despite intense pressure and deprivation. D'Aguiar also illustrates the limits to isolation by showing ongoing connections between the group and the government of Guyana in a back and forth flow of mystery suitcases between commune members and Guyanese soldiers, suggesting pay-offs. The outside world also enters in the form of the boat captain who befriends a woman and her daughter. Finally, local Amerindian tribes, who are shown as surrounding the commune on every side, frequently send delegations to trade with the community and to complain about river pollution.

D'Aguiar's book calls to mind the 1996 novel Jonestown by BritishGuyanese author, Wilson Harris, which also utilizes magical realism. ${ }^{50}$ Harris focuses on Guyana and lets the Americans blur into the background. Both authors propose that Jonestown is an act of colonialism. A white American leads mostly black American followers into a jungle, taking over indigenous territory, extracting what resources they can from the land and degrading the environment in the process. This enmeshes Jonestown in cross-cultural relations of power, complicating the symbol of isolation. The government did grant Jonestown a special status in Guyana, since the community operated, for the most part, independently of Guyana's laws, for example, in accrediting its school, licensing its physician, and getting things through customs (such as a chimpanzee) ${ }^{51}$ The people of Guyana were not told about Jonestown by their government. It was allowed an exceptional existence within the state and in relation to the Guyanese people.

Total isolation is a fiction, but relative isolation from the state is a privilege, an act of colonial power. Taussig foregrounds colonialism in his theory of mimesis and alterity: the overlapping of colonizer and colonized as both take over the other and become the other in an asymmetrical power relation. ${ }^{52}$ The Guyanese authors bring this complex and unstable relationship between colonizer and colonized into their reimaginings of Jonestown. The narrative of a white man taking African Americans out of their homes and into the jungle to exploit their labor and then kill them becomes a mimesis of slavery. It is 
significant that both Harris and D'Aguiar use magical realism, the technique famously employed by Colombian author Gabriel Garcia Marquez (1927-2014) to explore the phantasmagoria of South American colonial states. It is too horrifying to be real, but so horrifying that it cannot be denied. A dreamlike narrative is the only adequate way to explore the paradoxes and pluralities of this context.

Isolation is a powerful privilege to possess and terrifying to be within. Sedona offered relative isolation. It was a place people visited and moved to in order to escape their previous lives in larger, busier cities. My informants would refer to Sedona as a paradise. Jonestown was experienced as a paradise by some, the happiest time of their lives. ${ }^{53}$ However, too much isolation is the marking of the dangerous sort of group. This was the suspicion that spread in Sedona about Global Community Communications Alliance (GCCA), whose leader had moved the group in 2007 to Tubac, a remote desert area in the far south of Arizona, close to the border with Mexico. This move was viewed by people in Sedona as the group isolating itself.

When I visited GCCA in Tubac in autumn 2012 for Earth Harmony Day, the group promoted their practices of sustainable farming and permaculture. Taliaesyn, a member of GCCA, was at a stall selling produce from the community's gardens. When I asked, he told me the group moved from Sedona for more space and because corrupt local politicians imposed meaningless red tape on them. Spiritual growth for him was related to following the instructions of the leaders and elders, who had more experience. Back in Sedona, there were dark mutterings about sexual and financial exploitation of members. There was a Dateline exposé of the group in 1998, and a series of damning editorials in the local newspaper. ${ }^{54}$ The members of the group who I spoke to described what they were doing in edenic terms: establishing a self-sufficient agricultural paradise. For those in Sedona, however, they were seen as being controlled by an authoritarian leader. The dynamics of the relocation of Peoples Temple members to Guyana were replayed and reinvoked in debates over whether the movement of Gabriel's group was a dangerous sign. ${ }^{55}$

Isolation is a protective motion for those taking it on willingly; for those unwillingly isolated it is a symptom of an abusive relationship. As a symbol of why the deaths at Jonestown happened, it suggests that groups who isolate themselves from friends, family, and jobs are dangerous. Mimesis here again creates a warning sign, a way to learn the lesson of Jonestown: do not get isolated in the jungle with a mad man. The result can be toxic.

\section{POISON}

The enduring shorthand for Jonestown is "drinking the Kool-Aid," which is revealed by even a minimum of research to be problematic. ${ }^{56}$ 
The persistence of this language is rooted in its flexibility not its accuracy. It stands for more than simply the delivery mechanism: it stands for the poisoning of the mind by another; how the authority of a few can take over and dictate the terms of life and death to the many. It is a slippery symbol that can signify both the lethal result of being physically poisoned and the mental effects of being psychologically influenced and damaged by another.

The immediate coverage of the deaths focused acutely on the fruit punch and cyanide mixture. Emblematic of this is the Time magazine cover of 4 December 1978, with the headline "Cult of Death" and a color photograph of corpses piled up in Jonestown surrounding one of the metal tubs still half full of purple poison. ${ }^{57}$ The content was repeated in a 30-year anniversary edition photo essay. ${ }^{58}$ Pictures of bodies with faces obscured were captioned with brief statements about "indoctrination sessions" and survivor Odell Rhodes' statement about people walking up to take the adulterated drink as if "in a trance," displaying no emotion. Aerial shots of bodies established an undifferentiated mass, the lives of the members of Peoples Temple marked only by their deaths.

The phrase "drinking the Kool-Aid" has moved into American cultural argot. It started as a byword for unthinking followers and then became an indicator of loyalty when utilized in business and sports discourse. ${ }^{59}$ It continues to appear as an insult in political contexts. It was used against the supporters of both Hillary Clinton and Donald Trump in the run up to the 2016 United States presidential election. ${ }^{60}$ Before that it was applied to the supporters of Barack Obama in the 2012 election campaign. ${ }^{61}$ It is an easy way to denigrate political opponents. The symbol of "drinking the Kool-Aid" has flowed far beyond its source in American cultural history. A May 2017 article in the British tabloid The Daily Mail begins by announcing that the "typical cult" makes "strange demands" on its members before listing a range of different religious groups from different areas and historical periods, ending with a reference to Peoples Temple members who died by "drinking cyanide-laced Kool-Aid." 62 The writer argues that Britain's center-left Labour Party under leader Jeremy Corbyn is corrupting his followers, rendering them indifferent to reality, pursuing a list of enemies, and suffering from a sense of persecution. It is the other side who drinks the poison, whose brains are addled with toxic ideas.

This symbol resonates throughout popular culture representations of the deaths at Jonestown. The 2013 independent movie The Sacrament focuses on the deaths and the poison. ${ }^{63}$ The title refers directly to this, depicting the mass murder-suicides as a religious ritual for the group's members. It is shot in "found footage" style and aims at realism using a Vice documentary crew as a framing device. It repeats the well-known parts of the last days at Jonestown, with some shots imitating the NBC footage closely. It even uses patterned Dixie cups for the cyanide and 
shows people frothing at the mouth after drinking it. However, it also places the group in the present day, gives them little in the way of ideology (nothing in terms of socialism), and involves far fewer people than were in Peoples Temple. Most of the movie is taken up by the deaths. The arrival of the fictional Vice documentary crew quickly unravels the group. The plot immediately gives way to prolonged re-creation of the infamous pavilion scene, with the documentary crew fleeing for their lives as guards hunt them down with rifles. The act makes little sense, and while the preacher strongly resembles Jim Jones, as in The Veil, the audience is left to assume that the only reason for taking the poison is his command.

The ubiquity of the symbol of the poison and its simulation in popular media like The Sacrament is clearly a source of distress for survivors. In 2014 James D. Richardson, a childhood friend of Maria Katsarisa member of Jones' inner circle who died at Jonestown-wrote in the Washington Post that using the phrase "drinking the Kool-Aid" is offensive and suggested we stop saying it. ${ }^{64}$ In Richardson's opinion it is an inappropriate thing to say, especially when used positively in business contexts, because for many at Jonestown the ingestion of adulterated Flavor Aid was not voluntary. He claims that people were murdered there.

Despite protests such as Richardson's, the phrase lives on both in the media and in ordinary conversation. Roger's worry when deciding to leave Joe's martial arts group in Sedona was that he was submitting day by day to something that was increasingly harmful to him and his fellow students. It was at a training session, before Joe got there, that I heard the phrase "drinking the Kool-Aid." It was used as a joke by one of the students, but it rang out like an alarm bell. Jokes often reveal in jest what we are too afraid to say in seriousness. That morning it expressed what Roger later declared more clearly, before deciding to quit-the fear that they were in a cult.

I heard the phrase used again by those surrounding a man known in the local press as the "vortex jumper," Peter Gersten, who prophesied a portal opening on the top of Bell Rock in Sedona on 21 December 2012. ${ }^{65}$ Peter took people on hikes to the top of the 480-foot rock; he believed this was a ritual that would increase the likelihood of the portal opening. People contacted him through couchsurfing.com, a popular house-sharing website, and would stay with him while they visited Sedona and he would take them up Bell Rock. Afterward, he would take everyone who climbed with him out to dinner. In the week before the twentyfirst, around ten of us went to a Chinese restaurant, and after Peter ordered the tea, so did everyone else at the table. Two of the young women made "drinking the Kool-Aid" jokes. This time it did not express fear, but a comic reference to the rumors of a "suicide cult" surrounding Peter in the town. All these young people from out of town, staying with him, climbing that rock, and the old YouTube video in which Peter 
described how he believed a "leap of faith" off the rock was required to open the portal. ${ }^{66}$ It was another cult, wasn't it?

One of Peter's regular hiking buddies, Nick, helped Peter guide people to the top of Bell Rock. Nick confessed that he used to be a "horrible alcoholic," but quit drinking eleven years previously. He was impressed by Peter's conviction, but he said that he had not "drunk the Kool-Aid," in his own words. He wanted to see what would happen. I was struck by the contrast: a self-described alcoholic, who had spent years poisoning himself, with his current refusal to "drink the Kool-Aid." He used the term to establish his independence from Peter and to confirm to me that he would not follow without question, that he was not part of a cult.

The phrase "drinking the Kool-Aid" is mimicry as debasement. Nevertheless, the repetition of mimesis dilutes the poison, making it harmless. It becomes a way of stating whether one is in or out of a group that one suspects could be dangerous. The symbol of poison goes beyond its mode of delivery and stands for the concept of brainwashing. While this notion is controversial among scholars, it has an accepted meaning in popular culture. The mind is poisoned, which leads to a loss of control, and, in the worst cases, death. While mimesis of this trope in statements such as "drinking the Kool-Aid" operates as a warning, the symbolic potency of poison offers a means of expressing fear about cults in popular discourse.

\section{CONGLUSION}

Representations in popular culture of Peoples Temple concentrate on the repetition and diffusion of three symbols distilled down from a complex and messy historical reality. For Taussig, mimesis swings between essentialism and constructionism. ${ }^{67}$ Cults are dangerous religions. Cults are constructed as dangerous religions. But what is a cult? A cult is a religious group the speaker does not like, disagrees with the behavior and/or ideology of, and, if they are a member, a group they want to leave. It is a way of saying that the demands of this group have become too onerous, and one must leave this group for one's own safety or comfort or sense of self.

These symbols stand out more starkly if we consider what elements of Peoples Temple are not represented in popular culture. The California and Indiana periods, the ideology of socialism and racial integration, and the Temple's role in local, national, and international politics, are rarely included as anything more than brief backstory. Popular culture, however, retells a truncated version of the story, which then becomes the whole story in cultural memory. Peoples Temple is thought of as the story of a charismatic individual who isolated his followers and poisoned them mentally and then physically. In many representations, the only name that figures is that of Jim Jones; the members themselves are like 
the bodies on the cover of Time magazine, unidentifiable. When my informants in Sedona referred to Peoples Temple, it was through these three symbols of charisma, isolation, and poison. The story they knew was the end of the Peoples Temple story: Peoples Temple's legacy endures as the deaths at Jonestown.

Although distressing for survivors, it is the deaths that created the trauma. What happened at Jonestown rent a tear in the American social fabric. Through the process of mimesis the events of Jonestown have been memorialized and reinscribed. This distillation essentializes the term cult in a way that warns and teaches lessons. Meanwhile, the voices of the survivors are often neglected. Popular culture replicates and, in the process, replaces their meanings and their memories. As Teri Buford O'Shea said of the phrase "drinking the Kool-Aid," it "makes me shudder" but at the same time, "I know it's part of the culture now." 68 The symbols produced through mimesis both essentialize cults as inherently dangerous and construct all new religious movements as cults (and therefore inherently dangerous). An unstable process, as Taussig says, is also open to reinterpretation, as a way to find healing, to make sense of incomprehensible trauma, to make peace with the past by continuing it into the present. There are glimmers of these opportunities, but they have not yet emerged in the broader public understanding of either Jonestown or new religions.

\section{ENDNOTES}

1 Charisma has a vernacular definition evoking a sense of personal magic or magnetic appeal that a leader or well-known individual has, and this is the sense I am using. Scholars of religion use the term more often in the Weberian sense of a leader who lifts believers above and beyond their routine existence through their acceptance of his claims to special powers, see Thomas E. Dow, Jr., "An Analysis of Weber's Work on Charisma," The British Journal of Sociology 29, no. 1 (March 1978): 83-93.

${ }^{2}$ Rebecca Moore, "Drinking the Kool-Aid: The Cultural Transformation of a Tragedy," Nova Religio 7, no. 2 (2003): 92-100.

3 Jean Baudrillard, Simulations (New York, N.Y.: Semiotext(e), Inc., 1983); Max Horkheimer and Theodor W. Adorno, Dialectic of Enlightenment: Philosophical Fragments, ed. Gunzelin Schmid Noerr and Edmund Jephcott (Standford, CA: Stanford University Press, 2002); Walter Benjamin, "Doctrine of the Similar," (composed in Berlin early 1933), trans. Knut Tarnowski, New German Critique 17 (Spring 1979): 65-69.

${ }^{4}$ Michael Taussig, Mimesis and Alterity: A Particular History of the Senses (New York: Routledge, 1993).

${ }^{5}$ Essentialism is the reduction of a concept to a single essence and portraying this reduction as the whole, whereas constructionism is the multiplication of representations overlaying what is represented; Taussig, Mimesis and Alterity, 255. 
${ }^{6}$ John R. Hall, "The Apocalypse at Jonestown," in Cults and New Religious Movements: A Reader, ed. Lorne L. Dawson (Hoboken, NJ: Wiley-Blackwell, 2003), 187.

7 Rebecca Moore, "Peoples Temple: A Typical Cult?" in Introduction to New and Alternative Religions in America, Volume 2: Jewish and Christian Traditions, ed. Eugene V. Gallagher and W. Michael Ashcroft (Westport, CT: Greenwood Press, 2006), 114.

8 A process described in more detail in John R. Hall with Philip D. Schuyler and Sylvaine Trinh, Apocalypse Observed: Religious Movements and Violence in North America, Europe and Japan (London: Routledge, 2000), 15-18; Jane Dillon and James Richardson, "The 'Cult' Concept: A Politics of Representation," Syzygy: Journal of Alternative Religion and Culture 3, no. 3-4, (Winter-Fall, 1994): 185-197.

9 Eileen Barker, "From Cult Wars to Constructive Cooperation-Well, Sometimes," in 'Cult Wars' in Historical Perspective: New and Minority Religions, ed. Eugene V. Gallagher (London: Ashgate-Routledge, 2017), 10.

10 Rebecca Moore, "Jonestown and the Study of NRMs: How Survivors and Artists are Reshaping the Narrative of Jonestown," in The Bloomsbury Companion to New Religious Movements, ed. George D. Chryssides and Benjamin E. Zeller (London: Bloomsbury, 2014), 73-87; George D. Chryssides, “'From Deviance to Devotion': The Evolution of NRM Studies," in 'Cult Wars' in Historical Perspective: New and Minority Religions, ed. Eugene V. Gallagher (London: Ashgate-Routledge, 2017), 43-54.

11 Barker, "From Cult Wars to Constructive Cooperation," 9-22; Timothy Miller, "Are the Cults Wars Over? And If So, Who Won?" in 'Cult Wars' in Historical Perspective: New and Minority Religions, ed. Eugene V. Gallagher (London: Ashgate-Routledge, 2017), 33-42.

12 For two contrasting perspectives on the brainwashing debate see Eileen Barker, The Making of a Moonie: Choice or Brainwashing? (Oxford: Blackwell, 1984) and Stephen A. Kent, "Brainwashing Programs in The Family/Children of God and Scientology," in Misunderstanding Cults: Searching for Objectivity in a Controversial Field, ed. Benjamin Zablocki and Thomas Robbins (Toronto: University of Toronto Press, 2001), 349-378.

13 James A. Beckford, "The Continuum Between 'Cults' and 'Normal' Religion," in Cults and New Religious Movements: A Reader, ed. Lorne L. Dawson (Hoboken, NJ: Wiley-Blackwell, 2003), 26-30.

14 See Kristian Klippenstein, "Language Appropriation and Identity Construction in New Religious Movements: Peoples Temple as Test Case," Journal of the American Academy of Religion 85, no. 2 (2017): 348-380.

15 Barker, "From Cult Wars to Constructive Cooperation," 11.

16 Clyde Haberman, "What Doomsday Cults Can Teach Us About ISIS Today," The New York Times, 5 November 2017, https:/ /www.nytimes.com/2017/11/05/ us/retro-cults-isis.html.

17 Philip A. Vanno, "Ex-member says Church was 'Tyrannical,' Compares it to Jonestown,” Observer-Dispatch, 15 October 2015, http://www.uticaod.com/ article/20151015/NEWS/151019574. 


\section{Nova Religio}

18 I spent 13 months in Sedona and 9 months in Valle near the Grand Canyon completing ethnographic fieldwork for my doctoral dissertation in anthropology at the London School of Economics and Political Sciences, July 2012-April 2014. This research was funded by the Economic and Social Research Council.

19 Adrian Ivakhiv, Claiming Sacred Ground: Pilgrims and Politics at Glastonbury and Sedona (Bloomington, IN: Indiana University Press, 2001), 147. The United States Census Bureau population estimate for Sedona as of July 2016 was 10,036, https://www.census.gov/quickfacts/fact/table/sedonacityarizona/ PST040216, accessed 9 March 2018.

${ }^{20}$ Adrian Ivakhiv, "Red Rocks, 'Vortexes' and the Selling of Sedona: Environmental Politics in the New Age," Social Compass 44, no. 3 (1997): 36784; Guy Redden, "The New Age: Towards a Market Model," Journal of Contemporary Religion 20, no. 2 (2005): 231-46.

21 All personal names used in the ethnographic vignettes in this article are pseudonyms.

${ }^{22}$ Fondakowski, Stories from Jonestown, 9-13.

23 Fondakowski, Stories from Jonestown, 19-20.

${ }^{24}$ Fondakowski, Stories from Jonestown, 134.

25 James S. Gordon, “Jim Jones and His People," New York Times, 7 January 1979. http://www.nytimes.com/1979/01/07/archives/jim-jones-and-his-peopleguyana.html.

${ }^{26}$ Tom Retterman, "Evil in Paradise; Nov. 18, 1978: Remembering a massacre; Peoples Temple,” Edmonton Journal, 18 November 1998.

27 Jonestown: The Life and Death of Peoples Temple, directed by Stanley Nelson (New York: Firelight Media, 2006).

28 Stephen Holden, "Kool-Aid, Craziness and Utopian Yearning," New York Times, 20 October 2006, http://www.nytimes.com/2006/10/20/movies/ 20temp.html.

29 Jonestown: Paradise Lost, directed by Tim Wolochatiuk (Capetown: Film Afrika Worldwide and Cineflix Productions, 2007).

30 Matthew Thomas Farrell, "Peoples Temple as a Plot Device," the jonestown report 14 (October 2012), http://jonestown.sdsu.edu/?page_id=34251, last modified 30 May 2017.

31 Ryan Roy, Jonestown: A Novel (Ada, OK: Living Arts Publications, 2014).

32 Eugene Mendonsa, Jim Jones is Alive (CreateSpace, 2015).

33 The Veil, directed by Phil Joanou (Los Angeles: Blumhouse Productions, 2016).

34 There are examples of these kind of nuanced, balanced portrayals listed in the jonestown report under "Peoples Temple in arts and literature." Mary Lou Springstead takes on Jim Jones in a portrait in "The 'Trouble in Jonestown' Painting," the jonestown report 18 (November 2016), http://jonestown.sdsu. edu/?page_id=67644, accessed 30 October 2017. Robin S. Boyd tries an act of radical empathy in his poem in which he tries to evoke the "last hours" tape through the eyes of Jim Jones, "The Color of Fire - Part 1," the jtr bulletin (November 2014), http://jonestown.sdsu.edu/?page_id=61395, last modified 20 October 2014. 
35 Ann O'Neill, “Inside the Sweat Lodge: Witnesses Describe a Ritual Gone Wrong," CNN, 14 March 2011, http://edition.cnn.com/2011/CRIME/03/14/ ray.sweat.lodge.witnesses/index.html; Crimesider Staff, "Self-help Expert James Arthur Ray Gets 2 Years in Prison for 2009 Sweat Lodge Deaths," CBS News, 18 November 2011, https://www.cbsnews.com/news/self-help-expert-jamesarthur-ray-gets-2-years-in-prison-for-2009-sweat-lodge-deaths/.

36 Taussig, Mimesis and Alterity, 13.

37 Fondakowski, Stories from Jonestown, 137.

38 Fondakowski, Stories from Jonestown, 225.

39 Fondakowski, Stories from Jonestown, 206.

40 Fondakowski, Stories from Jonestown, 88-99.

41 The term 'White Night' is contested and I am using a broad definition. For further discussion of the term see "What are White Nights? How many of them were there?" one of the frequently asked questions at https://jonestown.sdsu .edu/?page_id=35371, last modified 6 October 2013.

42 Fondakowski, Stories from Jonestown, 212.

43 Jennie Rothenberg Gritz, "Drinking the Kool-Aid: A Survivor Remembers Jim Jones," The Atlantic, 18 November 2011, https://www.theatlantic.com/national/ archive/2011/11/drinking-the-kool-aid-a-survivor-remembers-jim-jones/248723/.

44 Mark NC, “Is Glenn Beck's Independence, USA The Next Jonestown?” News Corpse, 12 January 2013, https://www.newscorpse.com/ncWP/?p=8830.

45 Mark NC, "Is Glenn Beck's Independence, USA The Next Jonestown?"

46 David Mirkin, "Commentary for "The Joy of Sect," The Simpsons: The Complete Ninth Season (Los Angeles: 20th Century Fox, 2006), DVD.

47 Fred D'Aguiar, Children of Paradise: A Novel (New York: HarperCollins, 2014).

48 Taussig, Mimesis and Alterity, xviii.

49 Rebecca Moore, A Sympathetic History of Peoples Temple: The Moore Family Involvement in Peoples Temple (Lewiston, NY: Edwin Mellen Press, 1985), 74.

50 Wilson Harris, Jonestown (London: Faber and Faber, 1996).

51 Fielding M. McGehee III, "Jim Jones and the Guyana Government: A Symbiotic Relationship," the jonestown report 19 (November 2017), at http:// jonestown.sdsu.edu/?page_id=70275, last modified 24 October 2017.

52 Taussig, Mimesis and Alterity, 250-255.

53 Fondakowski, Stories from Jonestown, 206-207.

54 See David Sunfellow, “Transcript: Dateline's Exposé of Gabriel of Sedona (aka Gabriel of Urantia)," NewHeavenNewEarth Pulse, http://nhne-pulse. org/transcript-datelines-1998-expose-on-gabriel-of-sedona-aka-gabriel-ofurantia/, accessed 30 October 2017. The video recording is archived at "Preserving Dateline's Exposé on Gabriel of Sedona," American Cynic, 11 July 2012, http://americancynic.net/ $\log / 2012 / 6 / 21 /$ preserving_datelines_ expose_on_gabriel_of_sedona.html.

55 A collection of Sedona Red Rock News articles, editorials, and letters to the editors from local residents about Gabriel of Sedona and his group, Aquarian Concepts Community (as it was known at the time), illustrates the issues raised in the community: "Expose of Tony Delevin, AKA 'Gabriel of Sedona,' and his 
Aquarian Concepts Cult, 2005-2009,” http://rapeutation.com/Exposeof TonyDelevinGABRIEL.pdf, accessed 6 March 2018.

56 Rebecca Moore, "Drinking the Kool-Aid", 93. The actual punch drink was Flavor Aid, not Kool-Aid.

57 “Cult of Death: The Jonestown Nightmare," Time Magazine, 4 December 1978. http://content.time.com/time/magazine/article/0,9171,912249,00.html.

58 "Mass Suicide at Jonestown: 30 Years Later," Time Magazine, 18 November 2008. http:/ / content.time.com/time/photogallery/0,29307,1859872,00.html.

59 Moore, "Drinking the Kool-Aid," 97-98.

60 Bonnie Yates, "The Presidential Candidates and Jim Jones: Clinton and Trump Tarred by the Same Brush," the jonestown report 18 (November 2016), http://jonestown.sdsu.edu/?page_id=67666, last modified 28 October 2016; "Drinking the Kool-Aid 2016," the jonestown report 18 (November 2016), http:// jonestown.sdsu.edu/?page_id=67782, accessed 30 October 2017.

61 Jack Cashill, “Obama's Jonestown,” American Thinker, 16 November 2012, http://www.americanthinker.com/2012/11/obamas_jonestowns.html; Eileen F. Toplansky, "Obama and Jonestown," American Thinker, 25 March 2012, http://www.americanthinker.com/2012/03/jonestown_and_obama.html.

62 Dominic Sandbrook, "Mr Corbyn and Co Increasingly Remind Me of One of Those Deranged Californian Cults of the Seventies," Daily Mail, 10 May 2017, http:/ / www.dailymail.co.uk/debate/article-4490362/Mr-Corbyn-remindCalifornian-cult.html.

63 The Sacrament, directed by Ti West (New York: Worldview Entertainment and Arcade Pictures, 2013).

${ }^{64}$ James D. Richardson, "The phrase 'drank the Kool-Aid' is completely offensive. We should stop saying it immediately," The Washington Post, 18 November 2014, https://www.washingtonpost.com/posteverything/wp/2014/11/18/thephrase-drank-the-koolaid-is-completely-offensive-we-should-stop-saying-itimmediately/?utm_term=.0f42bbef5169.

${ }^{65}$ I spent 14 hours on top of Bell Rock with Peter and a group of his friends as well as journalists, police, and onlookers, on 21 December 2012 waiting for his portal to open. Although this date was considered by many to be the end of the Mayan long count calendar and therefore an augur of significant spiritual change, for Peter its significance was that it was the winter solstice. Since this disappointment he has made a new prediction that it will open on 21 December 2018. See Patrick Whitehurst, "Mayan Calendar Vortex Jumper Costs County \$838," Sedona Red Rock News, 29 December 2012, http://redrocknews.com/news/13-top-news/ 8968-vortex-jumper-costs-838; Eric Tsetsi, "Sedona Vortex Jumper Peter Gersten Wanders Home after Vortex Fails to Open," Phoenix New Times, 22 December 2012, http://www.phoenixnewtimes.com/news/sedona-vortex-jumper-peter-gerstenwanders-home-after-vortex-fails-to-open-6648932.

${ }^{66}$ Peter has since taken the video down from YouTube, but a copy is saved here: "Peter Gersten Bell Rock Leap of Faith," https://vimeo.com/38445566, accessed 7 November 2017.

67 Taussig, Mimesis and Alterity, 252.

${ }^{68}$ Gritz, "Drinking the Kool-Aid." 